\title{
RENCANA PENGEMBANGAN DAN KESIAPAN SIVITAS AKADEMIKA UIN RADEN INTAN LAMPUNG MENUJU AUN-QA
}

\author{
Deden Makbuloh ${ }^{1}$, Sucipto ${ }^{2}$, dan Ruswanto ${ }^{3}$ \\ deden_makbuloh@radenintan.ac.id \\ Universitas Islam Negeri Raden Intan Lampung
}

\begin{abstract}
Raden Intan Lampung State Islamic University (UIN RIL) as a State Islamic Religious College in Indonesia needs to gradually carry out various efforts to improve the quality of continuing education. The long-term quality of UIN RIL does not only cover national level competition, but also internationally. This study aims to examine the quality improvement process that has had a development and readiness plan for AUN-QA for the Academic Community of UIN RIL. Data collected is qualitative data. In accordance with the research design in order to find an overview of the planned development of UIN RIL and its readiness towards AUN-QA. The data sources in this study were taken from strategic planning documents and the opinions of the academics. Techniques for collecting data through documentation studies, deep interview, and participant observation. Non-structured interviews, so that data sources actively construct the cognitive world, and researchers try to capture the realm of that meaning. Analysis of data is collected simultaneously while collecting data with the principle of verstehen. The results of the study concluded that since the form changed from IAIN to UIN RIL development plans were discussed which were discussed in several stages and involved various stakeholders directed to the campus as an international reference. This can be seen in the vision, mission and objectives of UIN RIL. Likewise in priority programs and target targets there are points towards international scale achievements. The academics have welcomed with joy the change in form of IAIN to UIN RIL. All have stated that this is an opportunity to further develop the campus to reach international competition. Thoughts and energy were mobilized to develop UIN RIL towards becoming superior and competitive.
\end{abstract}

Keywords: strategic plan, competition, international, UIN RIL, AUN-QA

\begin{abstract}
Abstrak
Universitas Islam Negeri Raden Intan Lampung (UIN RIL) sebagai Perguruan Tinggi Keagamaan Islam Negeri di Indonesia perlu secara bertahap melaksanakan berbagai upaya untuk dapat meningkatkan mutu pendidikan berkelanjutan. Mutu UIN RIL secara jangka panjang tidak hanya mencakup persaingan tingkat nasional, namun juga internasional. Penelitian ini bertujuan untuk mengkaji proses peningkatan mutu yang telah memiliki rencana pengembangan dan kesiapan untuk $A U N-Q A$ pada sivitas Akademika UIN RIL. Data dikumpulkan yaitu data kualitatif. Sesuai dengan desain penelitian dalam rangka menemukan gambaran yang ada tentang rencana pengembangan UIN RIL dan kesiapannya menuju AUNQA. Sumber data dalam penelitian ini diambil dari dokumen renstra dan pendapat sivitas akademika. Teknik pengumpulan data melalui studi dokumentasi, deep interview, dan observasi partisipan. Wawancara non terstruktur, sehingga sumber data secara aktif mengkonstruksi dunia kognitifnya, dan peneliti berusaha untuk menangkap alam makna tersebut. Analisis data dikumpulkan secara simultan bersamaan dengan mengumpulkan data dengan prinsip verstehen. Adapun hasil penelitian disimpulkan bahwa sejak berubah bentuk dari IAIN menjadi UIN RIL telah disusun rencana pengembangan yang dibahas dalam beberapa tahap dan melibatkan berbagai stakeholders yang diarahkan kepada kampus menjadi rujukan internasional. Hal ini
\end{abstract}


terlihat dalam visi, misi dan tujuan UIN RIL. Demikian juga dalam program prioritas dan target sasaran terdapat point menuju capaian skala internasional. Para sivitas akademika telah menyambut dengan suka cita atas perubahan bentuk IAIN menjadi UIN RIL. Semua sudah menyatakan bahwa hal ini adalah kesempatan untuk mengembangkan kampus lebih luas lagi hingga mencapai persaingan internasional. Pikiran dan tenaga dikerahkan untuk mengembangkan UIN RIL menuju semakin unggul dan kompetitif.

Kata kunci: rencana strategis, persaingan, internasional, UIN RIL, AUN-QA

\section{PENDAHULUAN}

Pendidikan Islam memerlukan pengelolaan yang akuntabel. Sebab, jika pendidikan Islam dikelola apa adanya, bisa jadi akan ditinggalkan masyarakat. Mengapa? Sebab sekarang era profesionalisme. Pengelolaan yang profesional artinya siap menghadapi daya saing. Daya saing bukan hanya lokal atau nasional, tetapi juga internasional. Pendidikan Islam yang diselengggarakan perlu memperhatikan mutu. Universitas Islam Negeri Raden Intan Lampung (UIN RIL) perlu secara bertahap melaksanakan berbagai upaya untuk meningkatkan mutu pendidikan yang berkelanjutan. Mutu UIN RIL secara jangka panjang tidak hanya mencakup persaingan tingkat nasional, namun juga internasional. Sebab, era sekarang persaingan lembaga pendidikan menjadi semakin variatif. Melihat orientasi seperti ini, hanya lembaga pendidikan yang berkualitas yang sesuai dengan tuntutan masyarakat global yang dapat eksis dalam arena persaingan.

Abuddin Nata mengatakan bahwa pendidikan Islam banyak menghadapi problematika. (Nata, 2003) UIN RIL sejak 3 April 2017 UIN RIL memulai babak baru dengan orientasi dan tata kelola sesuai ortaker yang baru. Ibarat orang yang baru menjalankan hidup rumah tangga banyak tantangan baru; Ibarat juga membangun peradaban yang baru, dihadapkan pada tanangan baru. Inilah kondisi nyata UIN RIL yang baru menetapkan visi, misi dan rencana strategisnya tentu banyak tantangan baru. Atas dasar itu, mutu pendidikan di UIN RIL perlu mendapat perhatian utama dari semua pihak yang terkait mulai bagian perencanaan, bagian peningkatan dan bagian penjaminan mutu. Seluruh civitas akademika harus terlibat dalam perwujudan mutu pendidikan. Untuk mewujudkan cita-cita ideal tersebut, semakin jelas diperlukan landasan teori perbaikan mutu yang kuat didukung dengan data. Salah satu 
perkembangan yang sedang aktual yaitu adanya Asean University Network for Quality Assurance (AUN-QA).

Berdasarkan penelitian terdahulu, sudah ada penelitian yang meneliti mengenai kegiatan rencana pengembangan maupun kegiatas pada sivitas akademik yang ada di universitas (Amelia \& Mussadun, 2015; Candra, 2017; Lestari \& Indarjanto, 2017; Mujab, Satoto, \& Martono, 2014; Prasodjo, 2016; Prihatno, Liesnoor, \& Windraswara, 2014; Supriyanto \& Iswandari, 2017; Wijaya \& Damayanti, 2011) serta telah ada penelitian yang meninjau mengenai $A U N-Q A$ (Adelyna, Fauzi, \& Junaedi, 201AD; Refnaldi \& Arianto, 2017; Suharmanto, Hidayati, \& Zen, 2016) Namun belum adanya penelitian yang mengkaji proses peningkatan mutu dan rencana pengembangan. Maka, penelitian ini bertujuan untuk mengkaji proses peningkatan mutu yang telah memiliki rencana pengembangan dan memiliki kesiapan untuk $A U N-Q A$ pada sivitas Akademika UIN RIL

\section{METODE PENELITIAN}

Penelitian ini didesain dengan model penelitian kualitatif, penelitian ini menggunakan metode deskriptif analitis. Sumber data dalam penelitian ini diambil dari dokumen renstra dan pendapat sivitas akademika. Teknik pengumpulan data melalui studi dokumentasi, deep interview, dan observasi. Wawancara dilakukan non terstruktur, sehingga informan aktif mengkonstruksi dunia kognitifnya, sedangkan peneliti berusaha menangkap makna tersebut. (Mulyana, 2004) Peneliti memilah-milah data yang relevan dengan pokok permasalahan dan landasan teori yang sedang dibangun dalam penelitian ini. Analisis data dilaksanakan secara simultan dengan pengumpulan data dengan prinsip verstehen. Jenis analisis yang digunakan yaitu analisis kualitatif dengan model berpikir induktif. Prosedur yang dilalui dalam analisis data penelitian ini, dimulai dari koding, editing data, kategorisasi, tabulasi, sketsa gagasan, display data dan penafsiran data.

\section{HASIL PENELITIAN DAN PEMBAHASAN}

Edward Sallis mengungkapakan bahwa proses transformasi konsep TQM dari dunia Industri kedalam dunia pendidikan telah terjadi (Sallis, 1993) Ada istilah baru yang belum dikenal luas dalam bidang pendidikan yaitu customer. Sallis menegaskan 
bahwa dalam pendidikan sebenarnya ada yang disebut customer baik internal maupun eksternal. Sejalan dengan konsep TQM, maka customer tersebut perlu ditempatkn sebagai sasaran kepuasaan mutu layanan pendidikan yang diselenggarakan. Salis juga membahas alat bantu dan teknik pengembangan kualitas termasuk dalam perencanaan strategik. Perlu adanya framework mutu yang jelas, baik menyangkut makna maupun prinsip-prinsipnya.

Charles Hoy dkk mengkaji tentang pengembangan kualitas itu harus bergerak dari dalam secara internal menuju pengembangan lebih lanjut secara eksternal(Hoy, 2000) Pimpinan harus memiliki kemampuan mendeteksi kualitas internal untuk melangkah pada penjaminan mutu secara eksternal. Pengembangan mutu pada prinsipnya merupakan strategi dalam pemecahan masalah pendidikan. Oleh karena itu, masalah perlu dideteksi secara akurat dan cermat. Chester O. McCorkle dkk, mengkaji tentang manajemen di perguruan tinggi sebagai tantangan yang perlu dihadapi dengan penuh kematangan (O. McCorkle, 1982) McCorkle bertolak dari perencanaan yang mengarah pada pengembangan yang efektif dan efisien, dengan memanfaatkan sumber daya yang perlu ditata secara integrtif dengan proses perencanaan. Perlu ada evaluasi untuk mengukur kesuksesan program yang telah direncanakan. Dalam kaitan ini, perlu adanya aksi lanjutan berdasarkan pada hasil-hasil evaluasi. B.N Marbun mengkaji perkembangan mutu dan peran manajemen dalam program pengendalian mutu terpadu. Marbun mengaskan bahwa lembaga pendidikan perlu memiliki gugus kendali mutu. (Marbun \& Henryanto, 1985) Mike Robson mengkaji gugus mutu perlu dikembangkan dengan pedoman yang praktis. (Robson, 1989) Pendidikan sebagai organisasi perlu dikelola dengan baik. Kajian ini memberikan dasar-dasar yang kuat dalam administrasi pendidikan, baik teori, praktis dan bahan-bahan riset lanjutan.

M.N. Nasution mengkaji secara lugas mutu terpadu dengan segala piranti untuk perbaikan kualitas khususnya dalam dunia bisnis. Implementasi mutu dimulai dari fase persiapan, perencanaan dan pelaksanaan dengan langkah-langkahnya yang sudah didesain sedemikian rupa. (M.N.Nasution, 2005) Demikian juga Dorothea Wahyu Ariani juga membahas mutu terpadu dengan beberapa elemen penting yang harus dipahami seluruh sivitas akademika dan pelanggan turut serta menentukan kualitas. (Wahyu Ariani, 2003) Husni Rahim mengatakan bahwa perubahan-perubahan berskala 
global, lembaga pendidikan Islam, terutama UIN sebagai lembaga pendidikan tinggi, perlu mengambil langkah-langkah strategis agar dapat melakukan antisipasi. (Rahim, 2001) Dalam hal ini, visi yang dirumuskan perlu melihat kaitan antara UIN dengan masa depan Islam di Indonesia. Suatu organisasi harus memiliki visi yang berani agar tetap eksis. Visi yang berani merupakan unsur pokok dalam melakukan rekayasa ulang. Setiap organisasi pasti ingin hidup dalam perubahan zaman.

Sedangkan misi pendidikan berupa deskripsi mengenai tugas, kewajiban, tanggung jawab, dan rencana tindakan. Misi ini dirumuskan sesuai dengan visi lembaga pendidikan. Misi ini yang digunakan sebagai dasar tri darma perguruan tinggi meliputi pengembangan pendidikan/pengajaran, penelitian dan pengabdian masyarakat. Menurut A. Malik Fadjar, bahwa visi dan misi harus jelas dan tegas bertumpu pada kenyataan. (Fadjar, 2005) Oleh karena itu, kenyataan internal dan eksternal perlu diidentifikasi dengan baik ketika merumuskan visi dan misi.

Menurut Abuddin Nata, agar lembaga pendidikan Islam tetap eksis di tengah persaingan global, perlu memiliki strategi peningkatan mutu dan cara pengukurannya. (Nata, 2003) Perlu strategi yang bertumpu pada kemampuan memperbaiki visi zaman. Perlu dicermati bahwa mutu pendidikan mencakup elemen-elemen yaitu: 1) usaha memenuhi atau melebihi harapan pelanggan, 2) mencakup produk, tenaga kerja, proses dan lingkungan, 3) merupakan kondisi yang selalu berubah, apa yang dianggap bermutu saat ini mungkin dianggap kurang bermutu pada masa yang mendatang.

Menurut Azyumardi Azra bahwa dalam rangka perwujudan fungsi idealnya peningkatan kualitas sumber daya manusia, sistem pendidikan Islam harus senantiasa berorientasi kepada menjawab kebutuhan dan tantangan yang muncul dalam masyarakat sebagai konsekuensi logis dari perubahan.(Azra, 1999)

Pendidikan Islam memiliki kedudukan yang penting untuk menyiapkan sumber daya manusia yang bermutu. Lembaga yang paling kompeten menyiapkan sumber daya manusia berbasis keagamaan adalah lembaga pendidikan Islam. Filosofi demikian, lembaga pendidikan Islam dapat menghasilkan sumber daya manusia yang menguasi kemajuan di bidang iptek, sekaligus memperkokoh keimanan dan ketaqwaan. Peran strategis pendidikan Islam juga disinyalir oleh Abuddin Nata, bahwa dalam pendidikan Islam tidak hanya mementingkan intelektual, tetapi juga ketahanan mental spiritual 
yang dapat melahirkan kemampuan beradaptasi dan survive di tengah kehidupan global. (Nata, 2003) Dalam hal ini, pendidikan Islam harus merubah tantangan menjadi peluang, dan mengisi peluang tersebut secara produktif.

Menurut Malik Fadjar, sekurang-kurangnya ada empat hal yang harus dilihat dalam gerak pendidikan, yaitu pertumbuhan (growth), perubahan (change), pembaharuan (development), dan keberlanjutan (sustainability). Keempat hal ini merupakan iklim pendidikan. Iklim pendidikan yang baik yaitu terciptanya suasana pendidikan yang komunikatif, hidup dan manusiawi.(Fadjar, 2005)

Menurut E. Mulyasa, bahwa manajemen peningkatan mutu pendidikan merupakan suatu metode peningkatan mutu yang bertumpu pada lembaga itu sendiri, mengaplikasikan kemampuan teknik, mendasarkan pada ketersediaan data dan pemberdayaan semua komponen lembaga pendidikan untuk berkesinambungan meningkatkan kapasitas dan kemampuan guna memenuhi kebutuhan peserta didik dan masyarakat.(Mulyasa, 2005)

Menurut Peraturan Pemerintah RI No. 19 tahun 2005 tentang standar nasional pendidikan disebutkan bahwa standar pengelolaan yaitu berkaitan dengan perencanaan, pelaksanaan, dan pengawasan kegiatan pendidikan pada tingkat satuan pendidikan agar tercapai efisiensi dan efektivitas penyelenggaan pendidikan. Pengelolaan pada jenjang perguruan tinggi menerapkan otonomi perguruan tinggi yang dalam batas-batas yang diatur dalam ketentuan perundang-undangan yang berlaku memberikan kebebasan dan mendorong kemandirian dalam pengelolaan akademik, operasional, keuangan dan area fungsional kepengelolaan lainnya yang diatur oleh masing-masing perguruan tinggi.

Fungsi perecanaan antara lain menentukan kerangka tindakan yang diperlukan untuk pencapaian tujuan tertentu. Di sini dikaji kekuatan dan kelemahan, menentukan kesempatan dan ancamaan, menentukan strategi, kebijakan dan program. Perencanaan yang baik mempertimbangkan prinsip spesifik (fokus), misurable (terukur), atainnable (tercapai), reasonable (rasional), time (tepat waktu).

Merencanakan pada dasarnya menentukan kegiatan yang hendak dilakukan pada masa depan. Kegiatan ini dimaksudkan untuk mengatur berbagai sumber daya agar hasil yang dicapai sesuai dengan yang diharapkan. Dalam setiap perencanaan terdapat kegiatan seperti: 1) Perumusan tujuan; 2) pemilihan program; 3) identifikasi dan 
pengerahan sumber daya yang tersedia. Perencanaan merupakan jembatan yang menghubungkan kesenjangan antara keadaan masa kini dengan keadaan yang diharapkan. Meskipun masa depan tidak mudah diprediksi, namun perencanaan penting untuk menghindarkan sekedar kebetulan-kebetulan.

Perencanaan sebagai suatu proses intelektual yang menentukan secara sadar tindakan yang akan ditempuh dan informasi yang tepat waktu dan dapat dipercaya, serta memperhatikan perkiraan keadaan yang akan datang. Oleh karena itu, perencanaan merupakan rasionalisasi tindakan yang akan dilakukan di masa depan. Untuk itu, perencanaan membutuhkan data dan informasi agar keputusan perencanaan akurat dan tepat.

\section{Konsep Perencanaan Strategis}

Ada beberapa hal dalam keberhasilan perencanaan strategis:

a. Prosesnya strategis sebab melibatkan keadaan lingkungan yang dinamis dan terkadang tidak bersahabat. Organisasi nirlaba itu mempunyai banyak pilihan dalam menghadapi kebutuhan customers, ketersediaan dana, persaingan, dan faktor-faktor lain yang berubah-ubah. Sikap strategis menuntut kesadaran akan pilihan.

b. Perencanaan strategis itu sistematis dalam hal memerlukan fokus dan produktif. Proses tersebut menimbulkan serangkaian pertanyaan yang menolong perencana untuk memeriksa pengalaman masa lampau, menguji asumsi lama, mengumpulkan dan mencantumkan informasi baru tentang masa sekarang, dan mengantisipasi lingkungan di mana organisasi akan bekerja di masa depan. Proses itu juga membimbing perencana untuk terus-menerus melihat bagaimana program dan strategi yang menjadi komponennya cocok dengan visi.

c. Perencanaan strategis itu mencakup pemilihan prioritas tertentu membuat keputusan tentang tujuan dan sarana, baik dalam jangka panjang maupun pendek. Konsensus tentang prioritas harus dicapai pada banyak tingkatan, dari tingkat filsafat hingga tingkat operasional. Meskipun rencana strategis itu tidak sampai tingkat detail dalam rencana operasi tahunan. Tujuan jangka panjang mempunyai implikasi bagi tindakan jangka pendek: keduanya harus cocok satu sama lain agar rencana itu sah dan berguna. 
d. Proses itu membangun komitmen karena memungkinkan ada perselisihan dihadapi dengan konstruktif dan mendukung komunikasi dan koordinasi yang lebih baik. Proses ini memungkinkan dibangunnya konsensus yang luas, sehingga meningkatkan pertanggungjawaban di seluruh organisasi. Keterlibatan ini menjamin rencana strtegis itu akan digunakan secara giat untuk pedoman dan inspirasi. (Allison \& Kaye, 1997)

Proses perencanaan startegis itu dapat kompleks dan menantang sehingga meyakinkan bahwa proses perencanaan startegis itu berada di jalur yang benar. Strategi adalah prioritas atau arah keseluruhan yang luas yang diambil oleh organisasi: strategi adalah pilihan-pilihan tentang bagaimana cara terbaik untuk mencapai misi organisasi. Dalam setiap kasus, organisasi itu telah membuat pilihan jelas di antara pilihan yang bersaing tentang bagaimana cara terbaik untuk mengejar misinya. Proses perencanaan strategis menolong organisasi untuk mengidentifikasi berbagai pilihan strategis dan membuat pilihan cerdas dalam mengembangkan arah dan rencana strategis.

\section{Perencanaan Strategis Dan Perencanaan Operasional}

Konsepsi perencanaan strategis dan perencanaan operasional itu melibatkan dua pemikiran yang berbeda. Keputusan strategis sifatnya fundamental, berorientasi masa depan. Sebaliknya keputusan operasional itu pelaksanaan sehari-hari dari keputusan strategis. Keputusan-keputusan strategis itu senantiasa memiliki implikasi jangka panjang, sedangkan keputusan operasional cenderung memiliki implikasi jangka pendek.

Perencanaan strategis tidak selalu linier, mudah diramalkan, dan lancar. Hal ini adalah proses kreatif yang memerlukan keluwesan pemahaman segar. Proses itu bergerak maju, kadang mundur beberapa kali sebelum sampai ke rangkaian akhir keputusan. Bandingkan perjalanan nyaman naik kereta api, dengan naik roller coaster. Namun, kereta-kereta roller coaster pun sampai ke tujuan mereka, asalkan tetap di jalurnya. 
Tentu hanya rencana tidaklah membuahkan hasil. Tetapi, rencana yang disusun dengan baik meningkatkan peluang ke hasil yang dikehendaki. Perencanaan menolong anggota organisasi untuk memfokuskan perhatian pada prioritas yang tepat.

Rencana strategis organisasi bukanlah tujuan pada dirinya sendiri, melainkan sarana untuk mencapai maksudnya. Organisasi memutuskan bahwa dia ingin mencapai tujuan tertentu dan menentukan untuk menetapkan program guna mencapai tujuan itu. Kalau organisasi lain pada waktu yang sama telah memutuskan untuk menetapkan program yang sama, organisasi pertama dapat bekerja sama dengan organisasi kedua atau dengan suatu cara lain menyesuaikan rencana programnya tanpa mengubah tujuan awalnya.

Peters menyebut ini sebagai "ketat dalam tujuan-tujuan" (Peters, Thomas J Waterman, 1982) artinya, membangun keterlibatan yang kuat dengan maksud dan tujuan organisasi, sementara memungkinkan orang di dalam organisasi itu untuk secara kreatif menyesuaikan metode mereka supaya mencapai tujuan itu dengan cara terbaik, atau bersikap "longgar dalam hal sarana".

\section{Standar AUN-QA}

Asean University Network for Quality Assurance (AUN-QA) merupakan organisasi jejaring universitas di Asean yang memiliki tujuan utama untuk memperkuat dan memperluas kerjasama bidang pendidikan tinggi antar negara Asean. Salah satu program AUN QA yaitu melakukan penjaminan mutu program studi yang menjadi anggota AUN. Hal ini merupakan pengukuran secara sistematis, terstruktur, dan berkesinambungan dalam penjaminan mutu perguruan tinggi anggota AUN.

Namun demikian, AUN-QA bukanlah sebuah akreditasi, tetapi assesment. Oleh sebab itu, dalam prosesnya dilakukan self assesment (penilaian mandiri) dalam bentuk self assesment report (SAR). Selanjutnya, setelah perguruan tinggi melakukan SAR, maka ditentukan action for improvement berdasarkan hasil SAR tersebut. Langkah selanjutnya dilakukan proses visitasi oleh reviewer dari anggota negara Asean lain untuk memberikan masukan atas self assesment yang telah dilakukan oleh perguruan tinggi. Ada 15 kriteria dalam AUN-QA, yaitu: Expected learning outcomes, Programme specification, Perogramme structure and content, Teaching and learning strategy, Student assesment, Academic staff quality, Support staff quality, Student quality, 
Student advice and support, Facilities and infrastructure, Quality assurance of teaching and learning, Staff development activities, Stakeholders feedback, Output, and Stakeholders satisfaction.

\section{Rencana Pengembangan UIN Raden Intan Lampung}

Dalam melaksanakan misi besar UIN Raden Intan akan melakukan kerjasama dengan berbagai institusi perguruan tinggi di dalam maupun di luar negeri, institusi relevan milik pemerintah atau swasta lainnya. Hal ini dilakukan secara berkelanjutan untuk meraih nilai keunggulan melalui proses adaptasi, inovasi, dan antisipasi. Hal ini sangat diperlukan UIN Raden Intan dalam upaya mengembangkan ilmu pengetahuan, teknologi, seni dan budaya dalam konteks keislaman dan keindonesiaan yang mewarnai dunia internasional. Hal tersebut sangat relevan dengan UIN Raden Intan untuk menjadi suatu lembaga perguruan tinggi Islam yang mampu mengawal proses berlangsungnya integrasi nilai-nilai keislaman yang utuh dan berkesinambungan ke dalam kehidupan masyarakat Indonesia. Kemampuan ini antara lain dapat diperoleh lewat berbagai penelitian yang dilakukan baik kuantitatif maupun kualitatif dalam berbagai bidang ilmu, seni dan budaya(Makbuloh, 2017)

Mengingat arus deras globalisasi tidak saja diyakini telah menyuguhkan sejumlah kebaikan dan kemajuan namun ternyata juga telah mendorong akibat negatif yang tidak terantisipasi sebelumnya, maka upaya pengembangan keilmuan dan kelembagaan yang dilakukan perlu mengedepankan aspek akhlak al-karimah sebagai karakter utama, tentunya tanpa mengesampingkan aspek-aspek budaya lokal dan budaya bangsa Indonesia.

Searah dengan visi dan misi, maka tujuan UIN Raden Intan Lampung diarahkan untuk:

1. Menghasilkan mutu pengelolaan bidang pendidikan dan pembelajaran ilmu-ilmu keislaman integratif-multidisipliner sehingga lulusan dan sumber daya manusia UIN Raden Intan Lampung mampu bersaing nasional dan atau internasional;

2. Menghasilkan mutu riset unggulan terpadu dalam pengembangan ilmu keislaman dasar dan terapan sehingga layak dipublikasikan dalam berbagai jurnal bereputasi nasional dan atau internasional; 
3. Menghasilkan mutu pengabdian pada masyarakat berbasis riset sehingga masyarakat cerdas, spirit tinggi, berintegritas dalam berbangsa dan bernegara;

4. Menghasilkan mutu kerjasama dalam dan luar negeri sehingga UIN Raden Intan Intan Lampung sebagai eco-campus yang dirujuk oleh dunia pendidikan nasional dan atau internasional.

\section{Sasaran Pengembangan UIN Raden Intan}

UIN Raden Intan Lampung memiliki sasaran strategis sebagai arah capaian keunggulan dan daya saing nasional dan atau internasional yang dibagi dalam 11 (sebelas) sasaran utama yaitu: 1) Pendidikan, Pengajaran dan Kurikulum; 2) Penelitian; 3) Pengabdian pada Masyarakat; 4) Sumber Daya Manusia; 5) Mahasiswa dan Lulusan; 6) Administrasi Keuangan; 7) Sarana dan Prasarana; 8) Kelembagaan; 9) Penjaminan Mutu; 10) Tata Kelola; 11) Kerjasama. Masing-masing bidang utama tersebut, sasarannya dapat diuraikan sebagai berikut:

1. Peningkatan mutu input, proses dan hasil pembelajaran yang diselenggarakan di lingkungan UIN Raden Intan Lampung (S1, S2 dan S3) yang unggul sesuai dengan bidang keahlian dan spesialisasinya;

2. Peningkatan kegiatan penelitian berbasis hasil yang berdampak signifikan (high impact) yang bermakna hasil penelitian diarahkan untuk menghasilkan: a). Karya ilmiah yang tersebar luas secara internasional, b) Kekayaan intelektual yang berkontribusi terhadap pemecahan masalah di tingkat nasional dan global, c) Materi dapat diekstrak untuk memperkaya bahan ajar.

3. Peningkatan kegiatan pengabdian pada masyarakat berbasis riset sebagai layanan prima bagi masyarakat Indonesia;

4. Peningkatan jumlah dan kualifikasi tenaga dosen tetap memiliki NIDN sesuai kebutuhan program studi yang aktif maupun yang direncanakan;

5. Peningkatan mutu tenaga kependidikan yang profesional sesuai bidang keahlian dan skill yang diperlukan dalam melaksanakan tugas dan fungsinya pada unit kerja masing-masing;

6. Peningkatan prestasi akademik maupun non akademik mahasiswa yang berbudaya ilmiah serta lulusan yang memenuhi kompetensi sesuai Kerangka Kualifikasi Nasional Indonesia (KKNI); 
7. Peningkatan jumlah sumber-sumber anggaran yang bervariasi (APBN-PNBP) dan alokasi pembiayaan tri darma perguruan tinggi yang memadai berdasarkan unit cost per mahasiswa di atas Rp. 16 juta per tahun;

8. Peningkatan pemanfaatan lahan, gedung dan kelengkapan isinya secara terpadu yang sesuai tingkat kebutuhan berdasarkan standar akreditasi nasional (BANPT), akreditasi ASEAN (AUN-QA), dan atau akreditasi Internasional lain;

9. Peningkatan peringkat akreditasi A untuk program studi dan UIN Raden Intan Lampung serta masuk dalam 500 rangking dunia;

10. Peningkatan jumlah kapasitas IT sehingga memiliki pangkalan data terpadu, terintegrasi, sistemik, dan dinamis dalam kerangka sistem penjaminan mutu internal (SPMI) dan sistem penjaminan mutu eksternal (SPME) dengan perbaikan mutu berkelanjutan.

11. Peningkatan tata kelola yang kredibel, akuntabel, transparan, tanggung jawab dan berkeadilan dengan menganut sistem Manajemen Mutu Terpadu.

12. Peningkatan kerjasama dalam dan luar negeri yang memberikan manfaat kepada semua pihak dalam pertukaran kepakaran sumber daya manusia.

\section{Tonggak-Tonggak Capaian (Milestone) UIN Raden Intan}

UIN RI Lampung menetapkan milestone sebagai pijakan tahapan capaian keunggulan secara berkesinambungan. Dalam upaya mewujudkan kampus menjadi rujukan dunia dan masuk dalam daftar rangking universitas, perlu ditetapkan tonggak capaian sebagai prasyarat mewujudkan capaian berikutnya dari tahun ke tahun dengan prinsip perbaikan mutu berkelanjutan. Tahapan mutu yang akan dicapai oleh UIN RI Lampung yaitu:

1. Terwujudnya Akreditasi Program Studi 60\% Peringkat A BAN-PT tahun 20172019 dan tidak ada prodi akreditasi C;

2. Terwujudnya Akreditasi Perguruan Tinggi UIN RI Lampung Peringkat A BANPT tahun 2020-2022;

3. Terwujudnya Kampus UIN RI Lampung terakreditasi ASEAN (AUN-QA) tahun 2023-2025;

4. Terwujudnya Kampus UIN RI Lampung Masuk Rangking Dunia tahun 20262030 dan rujukan internasional. 
UIN RI Lampung perlu menetapkan strategi dalam mewujudkan visi, misi, tujuan, dan sasaran melalui tahapan capaian yang sistematis. Berikut ini beberapa hal terkait dengan strategi yang perlu dilakukan.

1. Peningkatan UIN Raden Intan Lampung disertai pengembangan fakultas dan program studi baru.

2. Mengembangkan perpustakaan online dalam upaya mewujudkan digitalisasi perpustakaan yang memberi kontribusi kepada dunia ilmiah (world scholarship)

3. Peningkatan kualitas dan kultur akademik perguruan tinggi dan penguatan peran lembaga penjamin mutu pendidikan dalam pengembangan norma, standar, prosedur, dan kriteria pendidikan tinggi yang inovatif

4. Pengembangan program standar manajemen nasional dan internasional (ISO) bagi perguruan tinggi

5. Peningkatan penggunaan Teknologi Infomasi dan Komunikasi sebagai backbone bagi seluruh kegiatan akademik di perguruan tinggi

6. Pengembangan research-based university yang mengintegrasikan ilmu agama dan sains

7. Peningkatan kerjasama dengan instansi pemerintah, perusahaan swasta dan dunia industri dalam penelitian, pengabdian masyarakat dan pemagangan bagi mahasiswa

8. Peningkatan akses dan partisipasi sivitas akademika dalam kompetisi, lomba, olimpiade, seminar dan pengembangan bakat mahasiswa tingkat nasional dan internasional

9. Memfasilitasi prestasi mahasiswa internasional

10. Melengkapi sarana prasarana bertahap setiap tahun berbasis kebutuhan akreditasi

Sejak ditetapkan status yang baru menjadi UIN RI Lampung, dipandang urgen dan mendesak untuk melakukan pengembangan, terutama dalam struktur kelembagaan, sehingga mengalami perubahan dalam internal tata kelola dan manajemen menjadi semakin kompleks, modern, dan berbasis teknologi. Sebab, tata kelola yang manual akan mengalami kesulitan dalam pengambilan keputusan manajemen terkait dengan pangkalan data. UIN RI Lampung perlu melengkapi pangkalan data yang terintegrasi 
dan sangat lengkap. UIN Raden Intan Lampung diproyeksikan memiliki 8 fakultas S-1 dan pascasarjana dengan 56 program studi dan peminatan yang mencakup empat bidang ilmu (agama, humaniora, sosial, dan sain), dan ilmu-ilmu terapannya dengan ortaker 2 Kepala Biro.

UIN RI Lampung akan tetap mengembangkan program studi ilmu-ilmu keagamaan di bawah Kemenag minimum 60\% dan ilmu-ilmu sain teknologi di bawah Kemenristek Dikti maksimum 40\%. Disamping itu, juga UIN RI Lampung komitmen pada jaminan mutu kelembagaan. Khusus Fakultas Syariah, akan dikembangkan Lembaga Bantuan Hukum sebagai lembaga berbasis kepada pengabdian dan pelayanan dan bantuan hukum bagi pihak yang membutuhkan, terutama kalangan kurang mampu.

Untuk mencapai target pengembangan di atas, UIN Raden Intan Lampung menerapkan 2 (dua) strategi pengembangan yang masing-masing bersifat gradual (bertahap) dan simultan (saling melengkapi). Pertama, strategi bottom-up. Artinya, beberapa prodi yang sudah eksis dan berjalan dikembangkan menjadi basis pendirian beberapa fakultas baru. Kedua, strategi top-down. Strategi ini ditempuh membangun 'rumah besar' UIN RI Lampung yang akan 'diisi' dengan prodi-prodi dan fakultas baru. Strategi ini terutama diambil untuk pengembangan fakultas-fakultas berbasis ilmu-ilmu sosial, ilmu-ilmu humaniora, dan ilmu-ilmu alam (natural sciences) sebagai bentuk integrasi antara ilmu-ilmu agama dan ilmu-ilmu umum.

Untuk mendukung capaian persaingan internasional, UIN Raden Intan tahun 2017 ini sudah mendapatkan dana bantuan IDB untuk pembangunan fisik dan non fisik kampus yang berwawasan lingkungan dalam pengembangan integrasi ilmu pengetahuan. Hal ini menunjukkan bahwa skema IDB mengarahkan kampus ini untuk go-internasional. Melalui dana IDB dibangun gedung fakultas saintek, laboratorium terpadu fakultas, gedung olahraga dan seni, serta gedung rektorat 9 lantai. Disamping itu melalui dana IDB juga dipersiapkan dosen dan karyawan untuk studi lanjut ke luar negeri dan program peningkatan kompetensi di luar negeri.

\section{Pandangan Sivitas Akademika dalam Perubahan UIN Raden Intan}

Respon sivitas akademika UIN Raden Intan Lampung terhadap perubahan satker biasa menjadi satker PK-BLU masih pesimis. Alasannya, karena mekanisme kerja dan perangkat pendukung untuk mengimplementasikan PK-BLU belum dibentuk. Apa yang 
sudah tertulis dalam dokumen usulan PK-BLU masih banyak yang belum ditaati. Pada saat yang sama, akibat dari fleksibiltas penggunaan anggaran PNBP Non Akademik cenderung untuk "diotak-atik" berdasarkan kehendak pimpinan, sehingga banyak mengalami revisi anggaran. Revisi anggaran adalah dibenarkan, namun harus tetap sesuai dengan dasar kebutuhan yang telah ditetapkan bersama dalam rapat kerja pimpinan. Akibat revisi anggaran yang berulang, maka proses penggunaan anggaran menjadi sangat lambat dan realisai program tertunda.

Respon sivitas akademika UIN Raden Intan terhadap SPMB PTAIN sangat positif. Pimpinan telah menunjukkan hal yang serius dalam mensukseskan program seleksi mahasiswa baru melalui SPMB PTAIN. Hal ini juga didorong oleh tuntutan SPM dalam PK-BLU bahwa tahun 2011, UIN Raden Intan Lampung harus menerima mahasiswa baru minimal 1.600 orang. Hal ini sudah tercapai bahkan melampaui target. Respon sivitas akademik UIN Raden Intan Lampung terhadap Akreditasi masih beragam antara optimis dan pesimis. Sebagian besar optimis karena sudah menjadi tuntutan dan kebutuhan internal tentang mutu kelembagaan. Sedangkan sebagian kecil pesimis, karena instrumen akreditasi yang baru, sehingga belum ada pola sebelumnya. Walaupun perpanjangan akreditasi, tetapi para ketua jurusan yang baru masih menilai belum mengetahui banyak data-data yang ada pada prodi tersebut. Respon sivitas akademika UIN Raden Intan Lampung terhadap sertifikasi dosen semuanya optimis dan positif. Hal ini dipandang sebagai upaya untuk meningkatkan kesejahteraan dosen sehingga dapat bekerja penuh perhatian di kampus. Namun demikian, masih tersisa persoalan yang belum direspon baik oleh sivitas akademika yaitu laporan kinerja setiap semester dan setiap tahun menjadi laporan pada Dirjen Pendis Kementerian Agama RI sebagai dasar untuk pembayaran tunjangan tahun berikutnya.

\section{KESIMPULAN DAN SARAN}

Berdasarkan hasil penelitian dapat disimpulkan bahwa sejak berubah bentuk dari IAIN Raden Intan menjadi UIN RIL telah disusun rencana pengembangan yang dikaji dalam beberapa tahap dan melibatkan berbagai stakeholders yang diarahkan kepada kampus menjadi rujukan internasional. Hal ini dapat dilihat dalam visi, misi dan tujuan UIN Raden Intan Lampung. Demikian juga dalam program prioritas dan target sasaran 
terdapat beberapa point menuju capaian skala internasional. Para sivitas akademika telah menyambut dengan suka cita atas perubahan bentuk IAIN Raden Intan menjadi UIN Raden Intan. Semua sudah menyatakan bahwa hal ini adalah kesempatan untuk mengembangakn kampus lebih luas lagi hingga mencapai persaingan internasional. Pikiran dan tenaga dikerahkan untuk mengembangkan UIN RIL menuju semakin unggul dan kompetitif.

Saran yang dapat diberikan adalah agar UIN RIL harus menegaskan kembali rumusan rencana kerja tahunan masing-masing unit kerja agar tidak menyimpang dari garis menuju persaingan internasional, mengimplementasikan apa yang sudah menjadi pedoman dalam renstra dan mendorong para sivitas akademika untuk menyusun langkah konkrit menuju standar AUN-QA. Akreditasi dapat dijadikan pilihan utama dalam penjaminan dan pengembangan mutu UIN RIL ke depan. Oleh karena itu, perlu pelatihan mutu secara terencana, bertahap dan terpadu untuk bersaing dalam bidang pendidikan tingkat ASEAN maupun internasional secara luas. 


\section{DAFTAR PUSTAKA}

Adelyna, Fauzi, A. M., \& Junaedi, A. (201AD). Kinerja Akademik Pasca Sertifikasi AUN-QA Pada Program Studi di Institut Pertanian Bogor. Jurnal Aplikasi Bisnis Dan Manajemen, 2(2), 183-195.

Allison, M., \& Kaye, J. (1997). Strategic Planning for Nonprofit Organizations. San Francisco: Jossey Bass.

Amelia, P. R., \& Mussadun. (2015). Analisis Kesesuaian Rencana Pengembangan Wilayah Pulau Dompak Dengan Kondisi Eksisting Bangunan. Jurnal Pengembangan Kota, 3(1), 26-39.

Azra, A. (1999). Pendidikan Islam : Tradisi dan Modernisasi Menuju Milenium Baru. Jakarta: Logos.

Candra, A. L. (2017). Analisis dan Rekayasa Proses Bisnis Pada Bagian Layanan Akademik di Sekertariat Fakultas Sains dan Teknologi Universitas MA CHUNG. Jurnal Teknik Industri, 12(3), 161-170.

Fadjar, A. M. (2005). Holistika Pemikiran Pendidikan. Jakarta: Rajawali Press.

Hoy, C. (2000). Improving Quality in Education. London: Falmer Press.

Lestari, A. T., \& Indarjanto, H. (2017). Analisis dan Rencana Pengembangan Jaringan Distribusi Air Bersih Unit Cabang Timur PDAM Kabupaten Klaten. Jurnal Teknik ITS, 5(2), 1-5.

Makbuloh, D. (2017). Process, Results, and Consequences of Madrasa Accreditation: A Case Study in Lampung, Indonesia. Advanced Science Letters, 23 (2). Pp. 948952., 23(2), 948-952.

Marbun, B. ., \& Henryanto, E. (1985). Pengendalian Mutu Terpadu. 1985: Pustaka Binaman.

Mujab, S., Satoto, K. I., \& Martono, T. (2014). Perancangan Sistem Informasi Akademik Berbasis Mobile WEB Studi Kasus di Program Studi Sistem Komputer Universitas Diponegoro. Jurnal Teknologi Dan Sistem Komputer, 2(1), 119-129.

Mulyana, D. (2004). Metodologi Penelitian Kualitatif. Bandung: Rosda Karya.

Mulyasa, E. (2005). Menjadi Kepala Sekolah Profesional. Bandung: Rosda Karya.

Nata, A. (2003). Manajemen Pendidikan: Mengatasi Kelemahan Pendidikan Islam di Indonesia. Jakarta: Kencana.

O. McCorkle, C. (1982). Management and Leadership in Higher Education. London: Jossey Bass Publishers. 
Peters, Thomas J Waterman, R. H. (1982). In Search of Excellence: Lessons from America's Best-Run Companies. New York: HarperCollin.

Prasodjo, R. S. (2016). Pemetaan Kesiapan Desa Menuju Desa Siaga di Lima Provinsi. Jurnal Ekologi Kesehatan, 9(3), 1248-1253.

Prihatno, T., Liesnoor, D., \& Windraswara, R. (2014). Pengembangan Program Transportasi Hijau Pendukung Mobilitas Dan Kinerja Civitas Akademika Universitas Negeri Semarang. Sainteknol, 12(2), 159-170.

Rahim, H. (2001). Arah Baru Pendidikan Islam di Indonesia. Jakarta: Logos.

Refnaldi, \& Arianto, M. A. (2017). The Voice Of Alumni in Curiculum Development: A Steo to Meet the Standards of the AUN-QA. Lingua Didaktika, 11(2), 138-145.

Robson, M. (1989). Gugus Mutu: Pedoman Praktis. Jakarta: Binarupa Aksara.

Sallis, E. (1993). Total Quality Management in Education. London: Kogan Page.

Suharmanto, Hidayati, M., \& Zen, E. L. (2016). Improving The Teaching And Learning Quality By Developing AUN-QA Based Course Outline. Bahasa Dan Seni, 41(2), 248-298.

Supriyanto, W., \& Iswandari, R. (2017). Kecenderungan Sivitas Akademika dalam Memilih Sumber Referensi untuk Penyusunan Karya Ilmiah di Perguruan Tinggi. Berkala Ilmu Perpustakaan Dan Informasi, 3(1), 79-86.

Wijaya, S. F., \& Damayanti, F. M. C. (2011). Evaluasi dan Rencana Pengembangan Penerapan Aplikasi Enterprise Resource Planning (ERP): Studi Kasus Pada PT Astra Graphia. ComTech, 2(2), 912-922. 